UDC 332.143

DOI https://doi.org/10.32838/2663-5984/2021/4.30

Mirzazade L.F.

Institute of Caucasus Studies of the Azerbaijan National Academy of Sciences

\title{
POLITICAL AND SOCIO-ECONOMIC PROBLEMS OF THE REPUBLIC OF INGUSHETIA
}

The proposed article is devoted to the analysis and understanding of the political, territorial and socio-economic problems of the smallest region of the Russian Federation - the Republic of Ingushetia (0.02\% of the territory of Russia). The choice of Ingushetia as an object of research is explained by its non-trivial history, cultural memory, national identity (halgadj), and the plight in the modern period. It would seem that the Ingush should have the advantage and trust of the central, federal government. After all, according to Russian historians, they voluntarily entered into an alliance with imperial Russia. This conclusion was based on a document signed on June 13, 1810 by Major General Delpotso and representatives of two Ingush clans, while other clans resisted the Russian conquest. In 1811, the Russian envoy of German origin, Moritz von Engelhardt, at the request of the tsar, visited mountainous Ingushetia and invited the Ingush to join Russia, promising many benefits from the tsar. But, the representative of the Ingush people rejected the offer, answering: "I see only the sky above the hat." [10] The Russian conquest of Ingushetia was extremely difficult, the Russian troops had to rely on the method of colonization: the extermination of the local population and the settlement of the territory by Cossack and Ossetian loyalists. In the middle of the XIX century, the Russians, together with the Ossetians, managed to colonize the Ingush land. During the Stalinist repressions from February 23 to February 29, 1944, 91250 Ingush were totally deported on false charges of collaboration. Nevertheless, many Ingush fought in the Red Army. After the collapse of the USSR, the Ingush fought a bloody war with their western neighbor, North Ossetia, for a large plot of land that was given to the North Ossetians after the first Stalin deportations. The Ingush lost this war. To this day, their sense of historical injustice not only persists, but also deepens in connection with the illegal territorial exchange with Chechnya. According to the author, the presence of Ingushetia in the global dimension is not obvious and significant. However, in the aspect of modern political and socioeconomic processes and world democratic achievements, the problems of the Ingush people definitely deserve attention. For deprivation, poverty, infringement of human rights, territorial narrowing with the approval of the Russian authorities currently continue to be present in the life of the Ingush. In fact, the Republic of Ingushetia in a mirror image is a sore spot of Russia, the driving force of which has always been the strict policy of the state and the ruler aimed at ensuring internal control. In the North Caucasus Federal District of Russia, in addition to problems of an ethnic nature, territorial disputes, there are political, social and economic conflicts. Opposition protests and the emergence of new trends are turning into challenges to segregation, a vivid example of which is Ingushetia.

Key words: stages, statehood, political history, constitutional foundations, civil society, coronavirus.

Introduction. The relevance of the research topic is due to the global progressive development proclaimed in the United Nations Millennium Declaration: "We recognize that in addition to individual responsibility to our own societies, we also have a collective responsibility for upholding the principles of human dignity, justice and equality at the global level.

Therefore, as leaders, we are responsible to all the inhabitants of the Earth, especially to the most vulnerable of them...

We believe that the main task facing us today is to ensure that globalization becomes a positive factor for all the peoples of the world..." [27] In this context, the Republic of Ingushetia is not only the smallest subject of the Russian Federation, but also the most vulnerable region, in which the political, territorial rights of the ethnic group, democratic freedoms are violated. In fact, the leading role in the region belongs to the central government of the Russian Federation, which was clearly demonstrated in the territorial dispute with the Chechen Republic. The current situation in the Republic of Ingushetia attracts the attention of independent researchers in the field of the Caucasus, politics, economics, international law, democracy and requires further analysis by specialists. 
The purpose of the study is to identify the true causes of the specific problems of the Ingush people, starting with the history of forced annexation to Russia, deportation, return, territorial narrowing, ignoring popular protests in the modern period and promising improvement of the situation in the Republic of Ingushetia.

Analysis of the latest research and publications. The political and socio-economic problem of the Republic of Ingushetia has a solid array of scientific studies with analytical conclusions, mainly by Ingush authors: A.Z. Akhmadov, E.H. Khasmagomadov, Z. Dzarakhova, D.V. Zayats, R. Alpaut, V. Nagaev, etc., as well as Russian - V.B. Kovalevskaya, V.A. Kuznetsov, V.A. Shnirelman, etc. The problem is also stated in the periodical press and in the global Internet network. However, its solution remains at the same stage, without qualitative changes, based on this, the research topic cannot be closed, it requires further analytical research.

\section{Stages of formation of the Ingush statehood.}

Traditionally, the characteristic of modern Ingushetia begins with its large-scale size, as the smallest subject of the Russian Federation. However, in this study, we will pay attention to the Ingush positioning as a decent, secular Republic with a developed civil society. On October 8, 2020, the people of Ingushetia celebrated the 250th anniversary of being part of the Russian state. The fateful date is the end of February 1770, when the union of Ingushetia and Russia was documented legally in the city of Kizlyar and then on March 15, 16 and 17, near the large settlement of Angusht. From that moment, the process of integrating the Ingush into the sphere of cultural influence of Russia began. Among the first Ingush enlighteners were Ch. Akhriev, A. Bazorkin, A.-G. Dolgiev. They collected valuable historical materials on the development of the national culture of Ingushetia bit by bit. It should be noted that the Ingush are the direct heirs of the world-famous Kobani culture. The ancestors of the Ingush people created wonderful architectural works: pyramid towers, temples, shrines, tombs proudly towering in the mountains. The Koban cultural heritage laid the foundations for the traditional development of professional art, which is as much in demand today as in previous times [17]. In the political aspect, this culture determines the conservative vision of the Ingush of modern world trends. Experience shows that cultural values can also influence the manifestation and formation of a conservative ideology. Some modern politicians and ordinary people associate the word "conservatism" with an obstacle to everything new. Although, in fact, the forms of resistance to change are sometimes correct. The three dogmatic approaches look quite qualitative.

The first includes epistemological motives, including dogmatism, intolerance of ambiguity, avoidance of uncertainty, the need for order, structure and completion, through persuasion and information through the process of motivated knowledge search in order to understand the situation.

The second approach consists of existential motives, such as self-esteem, loss prevention and terror management, for the purposes of crises inherent in human society.

The third approach is ideological motives, including the rationalization of personal interests, group dominance and systemic justification, when socio-political theories are used to focus on the social system as a whole, as well as psychological and ideological functions that a conservative orientation is able to perform.

It should be noted that all Russian foreign policy vicissitudes took place with the active participation of the Ingush, who courageously defended the interests of the common state. On the southern borders, being in the center of the intersection of the geopolitical interests of the countries of Europe and Asia, the Ingush performed important strategic tasks [12].

However, it should be borne in mind that the formation of the Ingush statehood was preceded by certain stages:

1. 1860-1880, when Ingushetia was part of the Terek region.

2. 1881-1883. being in the Vladikavkaz district.

3. 1884-1905, - in the Sunzhensky Cossack district of the department of the Tersk region;

4. 1906-1917, - as the Nazran district as part of the Tersk region.

5. 1918-1920, - as part of the Mountain Republic. The formation of the autonomous Mountain Republic reflected not only the centuries-old aspirations of the mountaineers for national self-determination, but also the national characteristics of the entire North Caucasus region.

6. 1921-1924. The period of Ingushetia's stay in the Gorskaya Autonomous Soviet Socialist Republic. In 1921, the idea of building a new national-state education of the peoples of the Terek Region was realized, and in 1924 the national Ingush autonomous region was formed, the first head of which was Idris Zyazikov.

7. The years 1925-1935 in Ingushetia are characterized by an increase in economic and cultural development. 
8. 1936-1944. On December 5, 1936, with the adoption of the new Stalinist Constitution of the USSR, the Chechen-Ingush Autonomous Region was withdrawn from the North Caucasus Territory and transformed into the Chechen-Ingush ASSR [19].

During the Great Patriotic War, tens of thousands of Ingush together with all the peoples of the country heroically fought on all fronts, from the defense of the Brest Fortress to the capture of Berlin. For courage, fortitude and mass heroism shown by the defenders of the city in the struggle for freedom and independence of the Fatherland, to the city of Malgobek in October 2007. By the decree of the President of the Russian Federation, the honorary title of the Russian Federation "City of Military Glory" was awarded [11].

9) 1992 - to the present. On June 4, 1992, the Law "On the Formation of the Ingush Republic as part of the Russian Federation" was adopted.

Today, Ingushetia multiplies its historical, cultural and spiritual heritage, its original traditions, generates public ideas and approaches. The strength and greatness of the people of Ingushetia is in unity, which provides one of the resources for overcoming socioeconomic and political crises.

Political history and constitutional foundations of Ingushetia.

Since June 4, 1992, the Republic of Ingushetia has been a subject of the Russian Federation, an agrarian and industrial republic. Since 2000, the capital of Ingushetia has been the city of Magas, translated from Ingush - "City of the Sun" [3, p. 1].

Since for the peoples of the North Caucasus, in particular, for the Vainakhs - Ingush and Chechens; Ossetians; Balkars; Karachays, the topic of the heritage of ancient Alanya, to this day does not lose relevance, is controversial with separatist attacks and introduces political disorder into the state of civil society, we will present a brief historical excursion into the medieval period of the region.

The territory of ancient Alanya stretched for $450 \mathrm{~km}$ in length from west to east and up to $120 \mathrm{~km}$ in width from north to south [5, p. 10-11]. The state existed in the Khazar Khaganate until the 1230s, until it fell under the Tatar-Mongol invasion [5, p. 16-21].

In the spring of 1238, the hordes of the Mongol Khan Batu (Batu), in order to complete the conquest of the region of the Central Pre-Caucasus, besieged the capital of the Alan state. For a month and a half, the residents held a siege. Then the Tatar-Mongols built battering guns and broke through the Alan gate; they stormed Ma'as and, turning it into ruins, burned it to ashes [7, p. 32].
Interestingly, eight centuries have passed, and still the dispute over the Alan heritage does not subside between the mountain peoples. First, for any region, this issue means involvement in the great history in which the Alans were one of the most powerful peoples in the North Caucasus, and being called "Alans" is a sign of prestige. Secondly, and no less important, this is the issue of territorial inheritance of Alanya. It should be noted that among the peoples of the North Caucasus, in addition to the Ingush, Ossetians, Karachays, and Balkars also claim the heritage of ancient Alanya.

Russian scientists have a certain view on this issue. Thus, according to the doctor of Historical Sciences of Karachay, Z.B. Kipkeeva, this scientific problem was initially tendentiously tied by European authors to political and ideological concepts about the "Iranianspeaking Scythians and Alans" and the "Indo-European family", in which there was no place for Turkicspeaking peoples, but there was for Iranian-speaking Ossetians. So they were "appointed" as descendants of the Alans and in the XIX-XX centuries. for a long time they were persuaded and persuaded to admit that they are Alans-aces-wasps. But, the latter stubbornly did not want to give up their self-designation "iron". Meanwhile, the Karachays and Balkars are the only people who have preserved the name "Alan" in their language as an address to each other. Archaeological monuments, linguistics, written evidence of medieval data support the theory of the Alan ethnogenesis of the Karachays and Balkars. However, the historical Alania included many peoples of the North Caucasus. It is not surprising that the "Alan trace" can be traced in the ethnogenesis, culture and language of various peoples [3]. Another Russian historian from North Ossetia, S.M. Perevalov, notes: "There is a rapid process of ethnogenesis of small nations in the North Caucasus, political elites need an appropriate historical mythology (because the Young peoples did not have a scientific history before the arrival of the Russians). The Alan theme surfaced immediately after the collapse of the USSR in the 90s as a replacement for the socialist utopia (previously it existed in a latent form). Then the prefix "Alania" appeared to the name of North Ossetia, and the name Magas - for the new capital of Ingushetia" [3].

When in 2017 the Ingush are on the site "Change. org" we published a petition demanding to "rename our Republic to Alania", which was followed by a sharp reaction from the society of North Ossetia. The Deputy Minister for Ethnic Affairs of Ingushetia, R. Miziev, responded to their attacks: "It is worth recalling, however, that there are references 
to the Alan heritage, for example, in the official toponymy of Ingushetia. First of all, the capital of the Republic - the city of Magas, has the same name as the capital of historical Alanya. In addition, at the initiative of the Mayor of Beslan Tsechoev, the triumphal arch "Alan Gate" was erected in Magas" [25]. The square on which the gates are erected is also called Alanskaya. The place for the construction of the capital of Ingushetia was determined on the basis of the assumption of the historian N. Kodzoev, who believed that the Alan settlement located in the upper reaches of the Erz-Eli River was a hut Boarz is the historical Ma'as [7, p. 180].

It should be noted that the dispute was also colored by Armenia. The Armenian historian S. Harutyunov called the Alanian inscriptions in the Chechen-Ingush (Nakh) languages "near-scientific". "Despite all the fragmentary nature of these inscriptions, there is no doubt that they are written in a language close to modern Ossetian and, thus, belong to the Eastern Iranian group of languages," he stated [23]. The conclusions of S. Harutyunov are quite understandable, because they want so much to adapt the Armenian language with Ossetian, and then put forward their claims to the territorial heritage of Alanya.

The regional problem of belonging of the North Caucasian peoples, including the Ingush, to the historical Alania in this political context is not accidental, since it has political consequences expressed in separatist conflicts.

As it is already clear, the Ingush have completely restored the city of Ma'as. They began to rebuild it on the site of the destroyed capital of Alanya in 1994 by order of the first president of Ingushetia Ruslan Aushev (from March 7, 1993 to December 28, 2001). A few years later, the new city, already called Magas, became the official capital of Ingushetia. The first construction of Magas began on February 23, 1994. On April 15, 1994, the decree "On the construction of the capital of Ingushetia" was signed. On April 3, 1998, a decision was made "On the name of the capital of the Republic of Ingushetia - the city of Magas". On September 11, 2000, the decree of the President of Ingushetia "On the formation of the Administration of the city of Magas" was issued. On December 26, 2000, the President of Russia signed the Federal Law "On the Proclamation of Magas as the capital of the Republic of Ingushetia" (instead of Nazran) [12].

The transfer of the capital from Nazran to Magas is a political step aimed at strengthening the power and authority of the president, which, accordingly, gives reason to consider the "capital" issue in a political aspect.
At the beginning of its independence, the national elite of Ingushetia put forward questions to neighboring North Ossetia about the territory and location of the republican capital, according to which it was supposed to be located in the eastern part of Vladikavkaz. The logic of the Ingush elite was based on the desire to return the administrative map of this region of the North Caucasus to the period 1924-1934, when the Prigorodny district, together with the right-bank Vladikavkaz, was part of the Ingush Autonomous Region (date of formation November 7, 1924).

However, what is the difference between the modern capital of Ingushetia - Magas?

Firstly, it has a favorable transport connection, just a few kilometers from it passes the federal highway Caucasus, $8 \mathrm{~km}$ away, in there is a railway station in Nazran and the national Airport is $30 \mathrm{~km}$ away. The city was specially revived and, practically, rebuilt to become the capital of the independent Republic of Ingushetia. In five years, modern administrative buildings, educational institutions, and the national television and radio company were built in Magas. In the center of the city on a spacious square stands the presidential palace, to the right of it is the parliament building, the mirror-symmetrical building on the left is occupied by the government. There are practically no historical monuments on the territory of this young city, the only attraction is the Presidential Ensemble and the Concord Tower, built in 2013. Ancient settlements have been discovered in the vicinity of the capital. More than 20 settlements with powerful defensive structures - deep ditches and earthen ramparts were built in wooded river valleys in the early Middle Ages [21].

The construction of the new capital, in fact, was Ingushetia's refusal to revise the existing administrative boundaries [6].

Paradoxically, the name of the modern capital of Ingushetia is replicated in Russia. For example, a self-propelled sea vessel of the reinforced ice class, built for Lukoil at the Admiralty shipyards in St. Petersburg, was named Magas [24]. Although the ship was launched twenty years ago, all its innovative systems remain relevant to this day. A series of ice tankers of this type is designed to facilitate regular navigation along the Northern Sea Route. What Magas copes with quite successfully [21].

It is difficult to answer the question: why the ice self-propelled vessel "Magas" with high technical characteristics was given this name. But, in 1941, when the Germans attacked the USSR, the entire Russian front went into retreat for $40 \mathrm{~km}$ a day. Of the 
6,500 defenders of the Brest Fortress, 6,000 Soviet soldiers surrendered. 500 soldiers were recruits of Ingush and Chechen origin. The defenders held the castle from the Germans for more than a month and even managed to launch several attacks from the castle. The name of the last defender was unknown for a long time; presumably it was Umatgirei Barkhanoyev. Decades later, official records showed that it was really him (a native of the Ingush village of Yandare). This story has a continuation. Not so long ago, the memoirs of a Lithuanian citizen, a former Waffen SS officer Stankus Antanas, were published in Ingushetia. It follows from his memoirs: in July 1941, he ordered his regiment to "finish off" the Soviet soldiers remaining in the fort. When the Nazis decided that one of the defenders had not survived, the SS general lined up his troops on the ceremonial square to reward those who had distinguished themselves during the capture of the fortress.

Suddenly, a Red Army officer came out of an underground bunker: blinded by injuries, he was walking forward with his left hand. His right hand was on the holster of his pistol. Holding his head straight, he walked through the parade and approached the bullet hole. Out of surprise, the German general greeted the Red Army soldier - the last defender of the Brest fortress.

The other officers followed the general. A Red Army officer pulled out a pistol and shot himself in the head. The Germans "froze" with admiration for the bravery of this man [13]. It was Umatgirei Barkhanoyev.

As it was already noted earlier, before 1992 Ingushetia repeatedly changed the status of its affiliation. Thus, by the decision of the first Mountain Congress held in Vladikavkaz, it was part of the multinational organization "Union of United Mountaineers of the Caucasus", the central committee of which was elected by the provisional government of the autonomous North Caucasian free State, or Mountain Republic, proclaimed in November 1917. The chairman of the Parliament of the Mountain Republic was Ingush Vasan-Giray Jabagi. The Mountain Republic declaratively covered the entire territory of the North Caucasus with its capital in Vladikavkaz, but its state structures, in fact, functioned only in Dagestan and soon fell under the onslaught of the Denikin Volunteer Army, which acted under the slogan: "For a united and indivisible Russia!". Having entered the borders of the Terek region, in early February 1919 Denikin launched an offensive against its center - the city of Vladikavkaz, held by Soviet forces. Part of their troops (three mounted divisions, a plastun brigade and other units), led by General Lyakhov, approached the Ingush villages of Kantyshevo and Dolakovo, which covered Vladikavkaz from the northeast. The whites demanded in an ultimatum form that the Ingush let them pass to the city. And, also, to compensate the Cossacks for the losses caused in the previous period (1917-1918), when armed skirmishes took place between the Ingush and neighboring Cossack villages, to extradite all the Reds who were on the territory of Ingushetia, and to form two horse regiments and two horse batteries for service in Denikin's army. Otherwise, General Lyakhov threatened to wipe out Kantyshevo, Dolakovo and other villages from the face of the earth. The Ingush refused, and the Whites with superior forces went on the offensive. In the area of the flat Ingush villages of Dolakovo, Kantyshevo, Bazorkino, Keskem, Psedakh, Sagopshi, stubborn battles unfolded. Thus began the first period of the Vainakhs' struggle with Denikin's army. When the civil war broke out in Russia, the Mountain Republic on May 11, 1918 declared its full independence and secession from Russia.

In the late 1920s and early 1930s, the Soviet authorities sought to establish the Chechen-Ingush merger as an "objective" and "natural" process [2, p. 98]. The Soviet linguist Nikolai Yakovlev, who was a supporter of unification, suggested that the inclusive name "veynakh" ("our people") should be used for both Chechens and Ingush. In his opinion, the rapid urbanization and rapprochement of Chechens and Ingush within one and the same republic can contribute to the formation of a common culture and language and the creation of a single "Veynakh" people. However, despite the common long-suffering history that the Ingush together with the Chechens experienced during the Second World War and after it (meaning the deportation of the Vainakhs), each of these peoples has the right to independent development.

The unjust deportation of the Vainakhs left an indelible mark in the chronicle of past years. During the period of Stalin's repressions, the Ingush, like many other peoples of non-titular nationality, were punished and thrown under the millstones of a hellish machine called "lentils". In the period from February 23 to March 9, 1944, from the territory of the Chechen-Ingush ASSR and the adjacent regions to Kazakhstan and Kyrgyzstan, from 500 to 650 thousand Chechens and Ingush were sent. 180 trains with the deportees were sent. One in four of them died on the road. The Chchen-Ingush ASSR was abolished, and the Grozny Region was created on its 
territory, part of the districts became part of North Ossetia, Dagestan and Georgia.

The reasons for the deportation were officially called collaboration (mass cooperation with the occupiers, anti-Soviet activities and banditry). Official data were falsified to justify the actions of the authorities. There are versions of the real reasons for the deportation, but they do not put all the dots over the "I". For example, the North Caucasus region is famous for its highly active radon-radium underground mineral springs.

Radon and radium are the decay products of uranium. In the oil fields of the North Caucasus (Chechen-Ingushetia), as a result of oil production in the pre-war and war years, radium and thorium salts contained in the earth's crust and delivered to the surface for many years polluted vast territories. The conducted studies of water sediments, soil and technological equipment for radioactivity in the area of oil fields indirectly confirmed the presence of uranium in the bowels of the North Caucasus. In the thirties, a large-scale geological exploration was carried out in the "rare earth" region of the North Caucasus. Geological maps of uranium deposits, places of uranium mining, secret military airfields were a state secret. Probably, the NKVD agencies also received information from the agents about the results of the exploration and search for uranium conducted by German mining engineers in the Caucasus and in the Crimea during the occupation. The radiometric equipment used in the USSR to indicate uranium was imperfect at that time (a transparent glass bottle with newspaper petals - an electroscope), often areas of terrain with increased radioactivity were unreasonably plotted on maps. However, the results of subsequent studies did not confirm the presence of uranium deposits and ore occurrences of industrial significance, or uranium minerals were located at a sufficiently deep depth [20]. It can be assumed that some top managers of the Soviet government had a false idea about the huge reserves of uranium located on the territory of the North Caucasus. Historians distinguish two key figures in the role of organizers of deportations - atomic marshal Beria and his closest associate-Kobulov. For the cleansing of the territories of the North Caucasus from the "accomplices of fascists" - Chechens and Ingush, Kobulov is awarded the Order of Suvorov I-th degree, for the operation to evict "German henchmen" in the Crimea (Crimean Tatars, Bulgarians, Greeks and Armenians), he is awarded the Order of the Red Banner, for the operation to evict "collaborators" (Turks, Kurds, Hemshils), he is awarded the Order of the Patriotic
War I-th degree. So, the statute of the listed orders lists specific feats for which the distinguished person could be presented for an award. There are no items in this list for organizing and conducting events related to the eviction of Balkars, Karachays, Chechens, Ingush, Crimean Tatars and other peoples to another area in accordance with the Decrees of the Presidium of the Supreme Soviet of the USSR with the stamp "Without publication". Consequently, Kobulov (and not only) was awarded high government awards not at all for carrying out measures to evict "collaborators". It should be noted an important fact, the immigrants were allowed to take with them only food and personal belongings weighing no more than $500 \mathrm{~kg}$ per family. Within 2-3 days, hundreds of thousands of mostly innocent people were deported. And where did all the livestock of the deported peoples of the Caucasus and Crimea go? Horses, mules, and donkeys could be used as pack transport. In addition, large and small cattle are a ready-made food base for the diet of countless prisoners of the GULAG archipelago - "uranium volunteers" in secret mining mines and tunnels.

The chronology of the adoption of important normative legal acts on the Soviet atomic project and the deportation of peoples was as follows:

- the resolution of the State Defense Committee of February 11, 1943 with the stamp "Top secret" became the starting point for the organization of work on the use of atomic energy for military purposes. On July 30, 1943, the State Defense Committee of the USSR adopted an order "On the organization of geological exploration, uranium mining and production of uranium salts".

On August 18, 1943, in pursuance of the order of the State Budget Committee of July 30, the Presidium of the USSR Academy of Sciences obliges:

- the Institute of Geological Sciences, the Radium Institute and the Laboratory of Geochemical Problems to draw up a plan of geological and prospecting works for uranium ores by September 25, 1943;

- the Azerbaijani (Caucasian) branch of the Academy of Sciences of the USSR to organize, from November 1943, testing for radioactivity of samples of rocks, ores and waters coming from geological parties.

- then, starting from October 1943, Decrees on the resettlement of Peoples were issued. On January 31,1944 , the GKO issued a decree on the deportation of all Chechens and Ingush to Kazakhstan and Kyrgyzstan. The code operation "Lentil" lasted from February 23 to March 9, 1944. In parallel, there was an operation to clean up the territory of the Elbrus region from the Balkar people according to the GKO 
decree of March 5, 1944. It should be noted that just on the eve of Operation Lentil, the first meeting of the heads of military intelligence and the NKVD on the atomic problem was held in the NKVD of the USSR under the chairmanship of Beria. On April 8, 1944, the State Defense Committee of the USSR ordered to begin extensive searches for uranium throughout the country. Some time later, mining engineers from the Koltsovskaya geological party discovered uranium deposits on Mount Beshtau and Mount Bull near the city of Lermontov, Stavropol Territory. They entered the history of the Soviet nuclear project under the names "Mine № 1" and "Mine № 2.”

However, the uranium deposits in the Caucasus turned out to be very poor. Uranium minerals were literally picked out by hands from small veins of ore occurrences. As the academician of the Russian Academy of Sciences, Doctor of Geological and Mineralogical Sciences A.M. Portnov, rightly noted, in the search excitement, the uranium miners almost ruined the resort areas of the North Caucasus. The real uranium deposits were discovered in the mid1950s on the mountain slopes of the Tien Shan within Kyrgyzstan, Uzbekistan and Tajikistan. Central Asia turned out to be the richest uranium-bearing province. At the same time, several major uranium deposits were discovered in Northern Kazakhstan. In other words, huge reserves of uranium were discovered in the area where Ingush and Chechens, Balkars and Karachays, Crimean Tatars and Meskhetian Turks were deported. It's a shame, because they are all anti-Soviet elements, collaborators. And here, you know, secret uranium deposits need to be developed urgently. And the "accomplices of the fascists" began to return to their mountain villages.

In 1957-1958 by the decrees of the Presidium of the Supreme Soviet, Chechens, Ingush, Karachay, Balkars and Kalmyks were allowed to return to their historical territories. The Soviet government, when making a decision on the genocide of peoples, was apparently guided by the accumulated world experience of the deportation of politically unreliable French-Acadians in France and England (XVIIXVIII centuries), the Japanese in the Hawaiian Islands after the attack of the Imperial Japanese Navy on the American fleet at Pearl Harbor. But in these cases, forced expulsion to another locality was carried out in relation to politically unreliable categories of the population. Mass deportation of the historical community of people was not carried out.

"The purpose of the deportation of certain peoples of the USSR during the Great Patriotic War was to clean up the territory for secret development of uranium deposits and the construction of secret nuclear industry facilities. The Soviet atomic project is the true reason for the deportation of peoples! If all the places of compact residence of the deported peoples are put on tracing paper, and then this thin sheet of transparent paper is superimposed on geological maps and reports of the Soyuzgeolfond, then the zones of deportation completely coincide with the zones of uranium deposits" [20].

This information goes from the category of versions to a FACT! Although, some questions remain open. So, how to explain the liquidation of statehood and the change of borders, in the specific case of the Vainakhs? The efforts to destroy traces of the indigenous population are incomprehensible. Russian and Ossetian names were assigned to settlements. Mosques and cemeteries were desecrated and looted, tombstones were used for construction and road works, books in the Chechen and Ingush languages were burned, references to Vainakhs were removed from the survivors. "Politically incorrect" exhibits were removed from museum collections, handwritten books and libraries, gold and silver jewelry, weapons, carpets, utensils, furniture, etc.were destroyed and looted. Although, these actions can be explained by banditry and pillaging. The actions of the authorities were not provided for by any legal or subordinate acts, and therefore were illegal $[1$, p. 836].

The restoration of the Chechen-Ingush ASSR occurred with the publication of Decrees of the Presidium of the Supreme Soviets of the USSR and the RSFSR on January 9, 1957, but its borders were changed. The Supreme Soviet of the USSR approved the decree of its Presidium and returned the mention of autonomy to the Constitution of the USSR. Chechens and Ingush were allowed to return to their homeland. Due to the ill-considered and inconsistent implementation of the decisions of the authorities and the resistance of part of the partySoviet nomenklatura in the center and on the ground, the restoration process was delayed, was fraught with many difficulties and created new problems. Due to mutual provocations and with the connivance of the republican authorities, more than 113 thousand representatives of the non-indigenous population left the republic in 1957 alone. At the end of the 80 s, along with separatist tendencies in the Soviet Union (including land problems between Chechens and Ingush), on September 9-10, 1989, the Second Congress of the Ingush People was held in Grozny, dedicated to "restoring the autonomy of the Ingush people within its historical borders with the capital in the right-bank part of the city of Ordzhonikidze". 
The Republic of Ingushetia was to be organized from six traditional Ingush districts (including the disputed Prigorodny District). After the collapse of the USSR, the Ingush were regained their independence. On June 4, 1992, after the division of the Chechen-Ingush ASSR into two parts, the independent Republic of Ingushetia of the Russian Federation appeared. In this regard, it became necessary to create and adopt the republican Constitution as the Basic Law, the most important and necessary element of the statehood of the new subject of the Russian Federation. On March 15, 1993, at the Extraordinary Congress of the People of Ingushetia in Nazran, the Declaration "On the State Sovereignty of the Ingush Republic" was adopted on February 27, 1994. The Constitution of Ingushetia was adopted on the basis of a popular vote. In it, the Republic of Ingushetia declared itself a democratic, legal, secular state, as part of the Russian Federation, formed on the basis of the exercise of the inalienable right to national and state self-determination [24].

In 1994-1996, Ingush volunteers fought together with Chechens in the First Chechen War. With the exception of a few incidents (including the killing of Ingush civilians by Russian soldiers), Ingushetia was largely excluded from the war thanks to the resolute nonviolent policy pursued by President Ruslan Aushev. The situation changed after the outbreak of the Second Chechen War, especially after Murat Zyazikov became the second president of Ingushetia appointed by Russia in 2002. The first major rebel attack occurred in May 2000, when 19 soldiers were killed. During a raid in Nazran in June 2004, Chechen and Ingush rebels attacked government buildings and military bases throughout Ingushetia, resulting in the deaths of at least 90 Ingush and an unknown number of Russian servicemen. Among them are the Acting Minister of Internal Affairs of the Republic Abukar Kostoev and his deputy Ziaudin Kotiev. In response to a sharp increase in the number of militant attacks since the summer of 2007, Moscow has tripled the number of special forces in Ingushetia, sending another 25,000 troops of the Ministry of Internal Affairs and the FSB.

The most important milestone in the history of the formation of the Ingush statehood is the adoption of the Constitution. Proceeding from the fact that the Constitution of the Republic of Ingushetia must comply with the federal legislation of the Russian Federation, in cases of amendments to the federal legislation, they must also be transferred to the Constitution of Ingushetia. The Constitution of Ingushetia is also being amended and supplemented due to the process of improving the regional Ingush legislation in political, economic directions and in matters of unresolved territorial disputes with neighboring republics.

So far, 25 amendments have been made to the Constitution of the Republic of Ingushetia.

The Constitution of the Republic of Ingushetia has binding force throughout its territory. It consists of a preamble, 11 chapters and 114 articles.

The preamble of the Constitution reads: "We, the multinational people of the Republic of Ingushetia, honoring the memory of our ancestors who bequeathed us the ideals of kindness, justice and love for the Fatherland, realizing responsibility for the historical fate of the statehood of Ingushetia, asserting freedom, rights and duties of a person and citizen, adopt the Constitution of the Republic of Ingushetia and proclaim it the Basic Law."

\section{Section I.}

- ch.1. Fundamentals of the constitutional system (art. 1-15);

- ch.2. Human and civil rights and freedoms (art. 16-63);

- ch. 3. The system of State authorities (art. 64);

- ch. 4. The Republic of Ingushetia (art. 65-71);

- ch. 5. People's Assembly of the Republic of Ingushetia (art. 72-82);

- ch. 6. The Government of the Republic of Ingushetia (art. 83-88);

- ch. 7. The judiciary and the Prosecutor's Office (art. 89-101);

- ch. 8. Local self-government and people's representation (art. 102-105);

- ch. 9. State symbols and the capital of the Republic of Ingushetia (art. 106-108);

- ch. 10. Administrative-territorial structure (art. 109-111);

- ch. 11. Constitutional amendments and revision of the Constitution (art. 112-114).

Section II. Final and transitional provisions (deleted).

The constitutional system in the Republic of Ingushetia of the Russian Federation.

In accordance with the Constitution, we will consider the basics of the constitutional system in the Republic of Ingushetia of the Russian Federation. This is a democratic, legal, secular state formed on the basis of the Ingush people's realization of their inalienable right to national and state self-determination.

Relations between the Republic of Ingushetia and the Russian Federation are regulated within the constitutional framework and by the Agreement on the Delimitation of Subjects of Competence and Powers between the federal state authorities of the Russian 
Federation and the state authorities of the Republic of Ingushetia within the Russian Federation. The names "Republic of Ingushetia" and "Ingushetia" are identical.

Within the limits of its powers, Ingushetia exercises all the fullness of state power and independently determines its administrative and territorial structure. The highest goal of the State is to ensure a decent life for every person, civil peace and harmony in society, the preservation and protection of the historical and cultural heritage of peoples, their national identity. All power in Ingushetia belongs to the people. The people exercise their power directly, as well as through State authorities and local self-government bodies. No part of society or individual has the right to appropriate power in the republic. Usurpation of State power is a crime. The Republic of Ingushetia carries out its own legal regulation throughout its territory, including the adoption of laws and other regulatory legal acts. State power in the Republic of Ingushetia is exercised on the basis of the separation and interaction of the three authorities: legislative, executive and judicial; as well as the division of powers between the republican and local authorities.

The unity of state power is ensured on the territory of the Republic of Ingushetia; the Constitution has the highest legal force in the republican system of normative legal acts; the established norms are valid throughout the territory of Ingushetia.

The Constitution, laws and other normative legal acts of state authorities and local self-government bodies must not contradict the Constitution of the Russian Federation and federal law.

All laws must be officially published. Laws that are not published in accordance with the established procedure for public review do not oblige citizens of the republic to execute them. State authorities and administrative bodies, officials, public associations and citizens are responsible for compliance with the Constitution and laws of the Republic of Ingushetia.

Various forms of ownership - state, private, municipal and others-are recognized and provided with equal legal protection. No one can be arbitrarily deprived of his property. The land, its subsoil, and other natural resources are used and protected in the Republic of Ingushetia as the basis of the life and activities of the peoples living in it.

Land relations in Ingushetia are regulated by federal and republican legislation. The return of the territory illegally seized from Ingushetia by political means and the preservation of the territorial integrity of the Republic of Ingushetia is the most important task of the state.
The highest official of the Republic is the head, elected by the deputies of the People's Assembly of the Republic of Ingushetia for a term of 5 years.

List of heads of Ingushetia:

- Ruslan Aushev - February 28, 1993 - April 28, 2002;

- Murat Zyazikov - May 23, 2002 - October 30, 2008 ;

- Yunus-bek Yevkurov - from October 31, 2008 to June 25, 2019;

- Mahmud-Ali Kalimatov from June 26, 2019.

During the rule of Ruslan Aushev, Ingushetia was an island of relative stability in the harsh politics of remote regions of Russia, sandwiched between the flames of war in Chechnya and the raging and even more complicated ethnic conflict in North Ossetia. For almost a decade, the history of post-Soviet Ingushetia has been the story of Ruslan Aushev, a dashing war hero from the Soviet campaign in Afghanistan. After his first election in 1993 (he was the only candidate and won with $99.94 \%$ of the vote). Ruslan Aushev led his republic from war to prosperity, hosting hundreds of thousands of Chechen refugees and several units of Russians. Aushev managed to protect the autonomy of Ingushetia and its culture. As a result, millions of dollars of investments were attracted. Aushev built a new capital on the outskirts of Nazran, named after the ancient city of Magas. Even his critics show respect. "Ruslan Aushev rendered a great service to the people," Magomed Yevloev said, "he raised the republic and was the only politician who always condemned the war in Chechnya. In fact, he was a white crow among crows." Having such support and entrenched power, Aushev, a year before the expiration of his term of office, announced the removal of them from himself. Aushev was the victim of an ouster organized by Moscow in order to push him out of the new presidential palace in Magas.

Shortly before Aushev announced his resignation, Vladimir Putin's personal representative in the Caucasus region, V. Kazantsev, a former commander of the Chechen campaign, sent his chief inspector there to find out where the money went in the offshore zone. On January 1, 2002, Aushev, like other regional leaders in Russia, was stripped of the immunity from prosecution granted by membership in the Federal Council, the highest governing body reorganized by Putin in his quest to restore the Kremlin's central authority. Ruslan Aushev himself appointed a new representative of Ingushetia in the updated Federation Council, thereby restoring immunity $[6$, p. 1$]$.

During the reign of Murat Zyazikov, the population of the republic increased by $12.1 \%$-from 
445.4 thousand people (2001) to 499.5 thousand (2007). This happened despite a decrease in natural growth: in 2001, 8,753 people were born in the republic, 1,875 people died; in 2007, 8,284 and 1,625 people, respectively. Citizens' incomes have almost quadrupled. However, Ingushetia was one of the poorest regions of the Russian Federation during this period. In 2001, the average monthly salary was 1,758 rubles (77th place among Russian regions), the pension was 854 rubles. In 2007 the salary increased to 7285 rubles (82nd place in the Russian Federation), the pension increased to 2977 rubles (the lowest indicator in the Russian Federation). The number of unemployed has almost quadrupled - from 11.6 thousand to 45.7 thousand people.

The budget revenues of the republic in 2001 amounted to 2.1 billion rubles, in 2008 they were planned in the amount of 8.59 billion rubles. At the same time, in 2001, Ingushetia received 1.2 billion rubles from the Federal Fund for Regional Support, and in $2008-5$ billion rubles. The gross regional product has grown by 2.5 times. In 2001, it was 3.6 billion rubles, and in 2007 it increased to 8.87 billion rubles. The growth rate of industrial production has decreased: in 2001, the industrial production index was $134.8 \%$ compared to the previous year, and in $2007-76 \%$ (the most significant decline in industrial production in Russia in 2007).

In 2001 the country was built 25.3 thousand square meters of housing in the first year of the presidency of Mr. Zyazikov, this figure dropped to 14.4 thousand square meters, and in 2007 increased to 32.8 thousand sq. $\mathrm{m}$.

The number of crimes in the country for six years grew by $20.9 \%$ - with 1740 in 2001 to 2104 in 2007 (82 in Russian) [4, p. 3].

The incident in the board of Yunus-bek Yevkurov began in the first month of the third term of his presidency. The Ingush accused their leader of concluding a land deal with neighboring Chechnya. Therefore, it is not surprising that in a post on the Russian social network "In Contact", the head of Chechnya, Ramzan Kadyrov, described Yevkurov's decision to resign as the decision of a man with a strong character, who, according to him, helped Ingushetia recover in the most difficult times.

In 2012, Yunus-bek Yevkurov publicly rejected an offer to visit (again) the Ingush-Chechen border. He warned that this would "lead to a conflict." In the same year, Yevkurov reproached Kadyrov for violating the borders of Ingushetia by conducting an anti-terrorist sweep in the Ingush village of Galashki.
In response, Kadyrov reproached Yevkurov for "sympathizing" with the militants.

Despite the disagreement, the two leaders agreed to conclude a land exchange deal in 2018. Having signed a deal with Chechen leader Ramzan Kadyrov, Yevkurov agreed to transfer 340 square kilometers (about $9 \%$ of the territory of Ingushetia) to Chechnya.

For a number of years, the Chechen authorities openly declared their rights to the territories in Eastern Ingushetia, despite the Chechen-Ingush agreement of 1993, as a result of which most of the Sunzhensky district remained part of Ingushetia. The statements of Chechnya, which relate to the Soviet maps of the 1930s, continued even after that, how the Ingush authorities agreed to transfer two villages to their neighbors in 2003.

Between 1936-1993 Chechnya and Ingushetia existed as the Chechen-Ingush Autonomous Soviet Socialist Republic, and the border between them was not drawn.

Yevkurov tried to sell the agreement with Chechnya, signed on September 26, 2018, as an "unprecedented" success story of a peaceful settlement of the conflict in the region. The population's distrust of Chechnya in Ingushetia grew in early September after the Chechen authorities began construction of a road connecting their southwestern Galanchozhsky district with Ingushetia. It is obvious that the people of Ingushetia learned about the deal postscript. On October 4, after the People's Assembly of Ingushetia adopted a bill on the official transfer of part of its territory in the Sunzhensky district of Chechnya, several deputies said that the vote was rigged and joined public protests against this deal in the capital of the country Magas. Here's how it happened: The exchange greatly favored Chechnya, which received 26 times more land than it gave away. The reactions of the Ingush were, of course, negative. In addition to the disproportionality of trade, Ingushetia will lose agricultural land and oil fields in the north, as well as mineral and forest resources in the south, while gaining two small areas of mainly mountainous territory. This will almost certainly have a negative impact on the already poor republic. In addition, the transaction was accepted in a very unclear and possibly invalid way. The public only found out about the deal after it had apparently already entered into force. The parliamentary vote that supposedly ratified it was ordered quickly and secretly. In addition, although the official result states that 17 deputies voted for the deal, 4 spoiled their ballots and 4 voted against, four deputies claim that these official results were falsified. They say that only 4 deputies voted for this deal, 4 spoiled their ballots, 
15 voted against and 1 abstained, while the hidden nature of the vote contradicted the constitutional norms of Ingushetia. The deal was announced only after Chechen troops were discovered on Ingush territory. Information sources have published maps created by German cartographers. Then Russian news channels downplayed the scale of the protests. In addition, on October 30, 2018, the Constitutional Court of Ingushetia ruled that the exchange of land plots was unconstitutional, since it required a public referendum, and not just a parliamentary vote. On December 6, the Constitutional Court of Russia ruled that the Ingush Court does not have jurisdiction in this matter, because the agreement has already entered into force and, since the border was actually canceled for the first time, a referendum is not necessary. Referendums are needed only when the border is changed. The court also ignored one of the main arguments of the court and the case, however, and did not say anything about the fact that the vote count was not confirmed, as required by law, and may have been falsified. The Chechen and Ingush leaders declared the case closed on the basis of the decision of the Constitutional Court of Russia, although the European Court noted that its decision does not actually legally cancel the decision of the regional court in accordance with the federal structure of Russia.

The protests apparently stopped within two days of the court's decision. However, the possibility of holding additional protest actions cannot be ruled out, and some civil society bodies are still insisting on the revision of the agreement, including, interestingly, by the Sharia court. The regional authorities have made some attempt to both prevent and take part in the ongoing protest actions. These included negative actions, such as the introduction of a moratorium on protests (which observers protested) shortly after the start of the first major protests, as well as slowing down or stopping Internet access in the capital to try to hinder the organization (young protesters apparently found ways to set up local networks and largely circumvent this). Positive steps included holding open meetings with experts and reports of closed meetings with protest leaders and Yevkurov. Relations with the protesters largely corresponded to Yevkurov's calm attitude to the authorities: requests for permits to hold protests were met, and the police generally supported the protests. Several thousand protesting people who appeared in small Ingushetia are indicative of broad public support [20]. In general, the opacity of the land swap and its disproportionality in the amount and value of the awarded land were the main reasons for the public discontent of the Ingush. Chechnya probably used the exchange of land as a way to achieve its political goals, gain more power, wealth and regional influence. The Kremlin's motivation was vague, it seemed that Kadyrov was allowed to realize his political goals. Moscow's relations with Chechnya are closer than with Ingushetia, so the Ingush receive less federal subsidies, and their land, with the permission of the federal government, is being reduced. In October 2018, the Ingush successfully challenged the land agreement in the local constitutional court, which ruled that this process violates the law on referendums. However, in December, this decision was overturned by the Federal Constitutional Court of Russia.

The people of Ingushetia also lost confidence in their leadership and began to demand Yevkurov's resignation.

On June 26, 2019, Mahmud-Ali Kalimatov was appointed head of the Republic of Ingushetia. He immediately began to change the local government, replaced the mayors of cities and districts, he was compromise and loyal with Moscow. [18]. In January 2020, a number of teips (Mogushkovs, Aushevs, Bekovs, Gazdievs, etc.) presented open claims to Kalimatov. In their opinion, the head was inactive on a number of demands of the people: first of all, concerning the territorial division with Chechnya, as well as the release from prison of his elders who protested against the illegal seizure of their territory. The head of Ingushetia, Kalimatov, publicly raised the issue of the release of the elders only one time. It happened at a January press conference in Magas. He said that "everything will be settled, the arrested will return home safely and that the case is being considered at the level of the prosecutor's office and the Investigative Committee of Russia for the North Caucasus Federal District."

It should be noted that Kalimatov also had conflicting relations with the Muftiate of Ingushetia. The late Mufti Abdurakhman Martazanov and the imams were against the rejection of the Prigorodny district in favor of the Chechen Republic.

On February 23, 2020, on the occasion of the 76th anniversary of the deportation of the Ingush people, the Teip Council asked Kalimatov to give them the floor at a funeral rally in Nazran. The people who came to the rally hoped to hear the speech of the members of the Council of Teips of the Ingush people. But, the elders were not given the opportunity to speak.

The Republic of Ingushetia, that under Yevkurov and his predecessors, that under Kalimatov remains depressed, subsidized and one of the poorest in Russia. 
According to Rosstat, the average salary in Ingushetia is no more than 19 thousand rubles a month, about $80 \%$ of families can afford only low-quality food and cheap clothes, they have no savings, they are unable to buy durable goods (furniture, computer, electric and household appliances, car, etc.), they use water from the water supply that is not suitable for drinking. It is difficult to blame Kalimatov personally for the economic degradation of the Republic of Ingushetia, because he has already come to the ruins of the economy [18].

Interaction of civil society institutions. The peculiarities of building a civil society in Ingushetia are still undergoing a period of their formation, since the awareness of a certain importance, of their key role in the life of Ingushetia, as a republic and a subject in general, occurred literally in the XX century, and the events of 2018 indicate that this awareness has been firmly established in the Ingush society. Currently, we are witnessing a period when society is ready to make decisions independently for the implementation of any kind of policy in the region, whether it is a sociopolitical component, socio-economic or even ethnoconfessional [13].

The key point is the fact that in addition to the norm established by the state, which characterizes society as civil, citizens themselves begin to realize their rights. This indicates that society functions as a civil society, and it is aware of its unity and integrity. That is, this organization as a social structure already has ideas about the rights that it can "promote" for the implementation of a particular issue that is vital for its full-fledged activity. Therefore, we can say that the civil society in Ingushetia is at the stage of its active life and active expression of will. In this regard, it should be noted the teip structure of Ingushetia, which has conservative beginnings, limited to the social structure itself. Teips are a certain stratum in the Ingush society, and it, of course, has its own specific features. The example of the events of 2018-2019 shows that the Teip structure quite harmoniously coexists with the concept of civil society, and it can perform the function that civil society itself actually performs, but necessarily taking into account the traditional norms and orders that have developed in teips historically. The only contradictory point about the tapes is that, as a social structure, it is closely tied by blood ties, and therefore may have a difference from all other tape organizations. This is not an entirely civil position of society, but the position of a specific social group a stratum. This is how it differs from the classical understanding of civil society. But when there is a problem from the outside or a threat to the fact of the existence of society as a whole, each of the tapes, in practice, shows a very similar position for each other. Therefore, at such moments, we can say that this contributes to the development of civil society. In Ingushetia, this looks most prominent, since here the forms of identity fluctuate between religious identity, which has its own structural characteristics, that is, it is not entirely confessional identity, but its certain subgroups, and ethno-cultural identity.

Some analysts have come to the conclusion that, despite the fact that all Ingush people characterize and identify themselves as Muslims, ethnic identity still prevails over all other types of it. In this regard, this is another confirmation that the Ingush are trying to preserve themselves, so it is not surprising that, for example, intra-ethnic marriages are still present as an attempt to preserve ethnicity. The attempt to preserve the ethnic language, although weakly, is still observed, and, of course, the number of an ethnic group, which is characterized by no more than 500 thousand people, as a small ethnic group, gives the very impetus when there is a need for self-preservation. Therefore, first of all, it is important for any representative of the Ingush people to emphasize their ethnic identity and only then will the other types of identity be voiced.

An important issue is the growth of the number of non-profit organizations in Ingushetia, including those of an ethno-cultural nature. This strongly reflects the current socio-political situation in the republic. The problem of the region is connected with the crisis caused by the economic downturn of development, high unemployment, high population density, low land. These indicators pose a serious problem in relation to social issues caused by the increase in poverty and people who cannot provide for their livelihoods. Therefore, mostly non-profit organizations are various kinds of charitable foundations, which, relying on such a traditional component as mutual assistance and mutual assistance, try to support such families, collectively, through fees. Just as it was in the past, when assistance consisted either of a teip initiative, or on a territorial basis, when neighbors, people living in the same village helped each other, etc.

This is an ethno-cultural component that is still observed today, but it functions in the new realities of life, through the activities of various forms of charity that focus on traditional ethnic and religious aspects. They are more successful, pragmatic and practical-such organizations are the most effective in the region. Now, in the conditions of the crisis, the role of such organizations is certainly beginning to increase, and this is quite a serious support for the general population. Since the Ingush are a 
conservative ethnic group, its public organization is closely connected with various collective principles, such as teips, virds, etc. But there is one very important specificity: it is that such traditional aspects as collectivism, mutual assistance, mutual assistance, various restrictions caused by the concept of taboo, ritual and ritual practices - all this makes up a huge layer, without which the Ingush cannot be identified as an ethnic group. This is an important aspect for the self-preservation of the identity that was already mentioned earlier. Therefore, it is necessary to note the following fact - in order to preserve the culture of an ethnic group, it is important to preserve those pillars of the ethnic component that would allow it to function in a dynamically developing world and society [17].

Since the Ingush will not be Ingush if they do not follow the basic characteristics of their culture, which is very specific and thus sharply differs from all other North Caucasian cultures. If we skillfully use the social structures that function among the Ingush society, we can say that they could fully contribute to the development of civil society, but on condition that people move away from their personal ambitions in favor of the interests of the national idea.

Ingush society during the coronavirus period. Ingushetia is the leader with the lowest number of coronavirus infections in terms of the incidence rate in the North Caucasus Federal District. There are 227.19 cases of infection for every 100 thousand of the population. North Ossetia is approaching this level, where there are 215.98 infections. Ingushetia is the leader with the lowest number of coronavirus infections in terms of the incidence rate in the North Caucasus Federal District. There are 227.19 cases of infection for every 100 thousand of the population. North Ossetia is approaching this level, where there are 215.98 infections. Ingushetia ranks fourth in the district in terms of the largest number of victims from the coronavirus. [15]

The head of Ingushetia, Mahmud-Ali Kalimatov, wrote on his Instagram account: "The work on identifying and checking for Covid-19 continues. He called on the residents of the republic to abandon skepticism about the spread of the virus" and "fully realize that we are facing an incredibly dangerous enemy." "Now is not the time for disbelief! Just one contact is enough for a series of fatal outcomes. We should not and cannot lose people because of carelessness, we cannot!" - Kalimatov stressed.

In Ingushetia, the percentage of those infected with coronavirus infection was low, as in other Muslim countries. This is due to the religious factor, before holding Namaz, Muslims perform ablution (dostamaz), and so six times a day, which reduces the spread of Covid many times. In 2020, for skeptics who did not believe in the coronavirus and ignored the protection measures and rules of self-isolation, the Minister of Health of the Republic of Ingushetia, Zarema Lyanova, officially offered an excursion to the infectious diseases building of the Nazran city Hospital, where patients with coronavirus are treated. Those who wished only had to purchase anti-plague suits [16].

To date, active vaccination is being carried out in Ingushetia. Those infected with Covid, if they are on self-isolation, have the consciousness not to go out and not spread the infection. People who have antibodies before vaccination are not allowed.

Conclusions. In the course of the conducted research, the features of the political and socioeconomic development of the Republic of Ingushetia of the Russian Federation were identified. An overview of the gradual formation of the Ingush statehood was presented. The article presents the characteristics of modern Ingushetia, which has been part of the Russian state for 250 years and, accordingly, in the process of Ingush integration into the sphere of Russian culture. The Ingush are the direct heirs of the world-famous Kobani culture, which, in the political aspect, "binds" them to the conservative vision of modern world trends. In accordance with dogmatic approaches, the Ingush developed a need for order, structure and completion. They have existential motives, such as self-esteem and loss prevention, as well as ideological motives, including the rationalization of personal interests, group dominance and systemic justification, when socio-political theories are used to focus on the social system.

All Russian foreign policy vicissitudes took place with the active participation of the Ingush. On the southern borders, being in the center of the intersection of the geopolitical interests of the countries of Europe and Asia, the Ingush performed important strategic tasks. The modern Republic of Ingushetia continues to generate public ideas and approaches. The most important milestone in the history of the formation of the Ingush statehood is the adoption of the Constitution. It is being amended and supplemented due to the process of improving the regional Ingush legislation in political, economic directions and in matters of territorial disputes with neighboring republics. The Republic of Ingushetia carries out its own legal regulation throughout its territory, including the adoption of laws and other regulatory legal acts. However, the federal 
government ignores the Basic Law, which is a violation of the rights of the nation.

The highest goal of the State is to ensure a decent life for every person, civil peace and harmony in society, the preservation and protection of the historical and cultural heritage of peoples, their national identity.

In terms of Russian politics, nothing has changed, it is traditional, "Divide and rule". However, in our opinion, in the near future, the global democratic process will still make its own adjustments.

The peculiarities of building a civil society in Ingushetia are still undergoing a period of their formation, since the realization of a certain importance, its key role in the life of Ingushetia, as a republic and a subject as a whole, occurred literally in the
XX century. Currently, we are witnessing a period when society is ready to make decisions independently for the implementation of any kind of policy in the region, whether it is a socio-political component, socio-economic or even ethno-confessional. The problem of the region is connected with the crisis caused by the economic downturn of development, high unemployment, high population density, low land. These indicators pose a serious problem in relation to social issues caused by the increase in poverty and people who cannot provide for their livelihoods. It is impossible to throw the blame on the economic crisis in the republic in connection with the global pandemic, because the Ingush are the leader with the least number of coronavirus infections in terms of the incidence rate in the North Caucasus Federal District.

\section{References:}

1. Ахмадов Я.3., Хасмагомадов Э.Х. История Чечни XIX-XX вв. Москва : Пульс, 2005. 996 с.

2. Aruuke Uran kyzy. Chechnya-Ingushetia territorial tensions benefit Putin. URL: https:/www.trtworld.com/ opinion/chechnya-ingushetia-territorial-tensions-benefit-putin-21811/2018/11/20.

3. Анчабадзе Г.З. Вайнахи. Тбилиси, 2001, 98 c. URL: https://www.kavkaz-uzel.eu/system/uploads/article_ attachment/attach/0000/3103/Вайнахи.Pdf

4. Краткая справка «Об административно-территориальных изменениях Ставропольского края за 1920-1992 годы». URL: http://stavkomarchiv.ru > userfiles > file > Pdf

5. Дзарахова 3. К ингушской государственности. 4 июня 1992 г. подписан Указ о создании Республики Ингушетия. URL: https://gazetaingush.ru/obshchest-vo/4-iyunya-1992-byl-podpisan-ukaz-o-sozdaniiingushskoy-respubliki/2020/07/06

6. Гладырев С. Ледяной танкер «Магас» в составе флота Лукойл. URL: https://rusone.ru/obschestvo/ transport/20190625-ledovyj-tanker-magas-v-sostave-flota-lukojl

7. History of Magas. URL: https://101hotels.com/recreation/russia/magas/history/Accessed :2021/07/28

8. Ингушетия отмечает 250-летие в составеРоссийского государства.URL:https://www.samddn.ru/novosti/ novosti/ingushetiya-otmechaet-250-let-v-sostave-rossiyskogogosu-darstva/2020/10/05/Информационный портал о дружбе народов

9. Ingușetya-İngushetia. URL: https://tr.qwe.wiki/wiki/Ingushetia/Accessed:2020/03/16

10. В Ингушетии коронавирус выявили еще у 91 человека. URL: https://regnum.ru/news/society/3049902. $\mathrm{html} / 2020$

11. В Ингушетии предложили экскурсию в инфекционный корпус для тех, кто не верит в коронавирус. URL: https://tass.ru/obschestvo/8222295?utm_source=yxnews\&utm_medium=desktop/2020/04/12

12. Ингуши пытаются сохранить себя. / Из интервью Ислама Ахциева с Танзилой Чабиевой о гражданском обществе в республике. URL: https://gazetaingush.ru/obshchestvo/intervyu-islama-ahcieva-dlya-gazetyingushetiya-s-tanziloy-chabievoy-o-grazhdanskom/21.05.2020

13. Годовой рубеж Калиматова: хронология и оценки. URL: https://fortanga.org/2020/06/godovoj-rubezhkalimatova-hronologiya-i-otsenki/3.11.2020

14. Кузнецов В.А. Алания в X-XIII вв. Орджоникидзе : IR, 1971. С. 10-21. URL: https://ru.wikipedia.org/ wiki/\%D0\%90\%D0\%BB $\%$ D0\%B0\%D0\%BD $\%$ D0\%B8\%D1\%8F

15. Нагаев В. Уран - истинная причина депортации народов! URL: https:/diletant.media/ blogs/72387/39835503/2018/03/31

16. Протесты в Ингушетии: хроника передела границы с Чечней. URL: https:/www.kavkaz-uzel.eu/ articles/326282/2021/07/36

17. Шнирельман В.А. Быть аланами: интеллигенция и политика на Северном Кавказе в XX веке. Москва : Новое литературное обозрение, 2006. 348 с.

18. Битва за Магас. Осетины и ингуши борются за право называться аланами / Кавказский узел. URL: https://www.kavkaz-uzel.eu/articles/298633/ 2017/04/14

19. Конституция Республики Ингушетия (принята 27 февраля 1994 г.) (с изм. и доп.) URL: http://constitution.garant.ru/region/cons_ingush/chapter/b6e02e45ca70d110df0019b9fe339c70/ 
20. Результаты редактирования Мурата Зязикова. Газета «Коммерсант» 199 от 31.10.2008 г. С. 3. URL: https://www.kommersant.ru/doc/1050130/3.11.2008

21. Борьба за аланское наследие. Кавказ. Реалии. URL: https://www.kavkazr.com/a/epidemiya-alanskogonaslediya/28343893.html/ 2017/03/03

22. Тува и Ингушетия: где живут самые бедные россияне /Газета. Ru, July 8, 2019. URL: https://finance.rambler.ru/economics/42460597-tuvai-ingushetiya-gde-zhivut-samye-bednye-rossiyane

23. Tyler P.E. In Caucasus, the Peaceful Separatists/ (Article in original context of February 2, 2002, section A, p. 1). URL: https://www.nytimes.com/2002/02/02/world/in-caucasus-the-peaceful-separatists.html/2002/02/02

24. United Nations Millennium Declaration. URL: https://www.un.org/ru/documents/decl_conv/declarations/ summitdecl.shtml/ Accessed: 2021/07/25

25. Заяц Д.В. Магас - «Город Солнца» - новая столица Ингушетии. Новости географии. Ж. География. № 11. 2002. URL: https://geo.1sept.ru/article.php?ID=200101106

\section{Мірзазаде Л.Ф. ПОЛТТИЧНІ ТА СОЦАЛЬНО-ЕКОНОМІЧНІ ПРОБЛЕМИ РЕСПУБЛІКИ ІНГУШЕТІЯ}

Пропонована стаття присвячена аналізу та розумінню політичних, територіальних $і$ сочіальноекономічних проблем найменшого регіону Російської Федераиї-Республіки Інгушетія (0,02\% території Росії). Вибір Інгушетії як об 'єкта дослідження пояснюється ії нетривіальною історією, культурною пам'яттю, національною ідентичністю (халгадж) $і$ тяжким становищем у сучасний період. Здавалося б, щчо інгуші повинні мати перевагу та довіру центрального, федерального уряду, адже, на думку російських істориків, вони добровільно уклали союз із імперською Росією. Цей висновок був заснований на документі, підписаному 13 червня 1810 р. генерал-майором Дельпочо та представниками двох інгушських кланів, тоді як інші клани чинили опір російському завоюванню. У 1811 р. Російський посланеиь німецького походження Моріи фон Енгельгардт на прохання иаря відвідав гірську Інгушетію i запросив інгушів приєднатися до Росії, пообіиявщи багато переваг від иаря, але представник інгушів відхилив пропозицію, відповівши: «Я бачу тільки небо над капелюхом» [10]. Російське завоювання Інгушетії було надзвичайно важким, російським військам доводилося спиратися на метод колонізаиії: винищення місцевого населення та заселення території козаками й осетинами. У середині XIX ст. росіяни разом з осетинами вдалося колонізувати інгушьку землю. Під час сталінських репресій із 23 по 29 лютого 1944 р. 91250 інгушів були повністю депортовані за фальшивими звинуваченнями у співпраці. Тим не менш, багато інгуші воювали у Червоній Армії. Після розпаду СРСР інгуші вели кровопролитну війну зі своїм західним сусідом, Північною Осетією, за велику земельну ділянку, яка була надана північноосетиниям після перших депортаџій Сталіна. Інгуші програли июю війну. Їх почуття історичної несправедливості не тільки зберігається, але й поглиблюється у зв'язку з незаконним територіальним обміном із Чечнею. На думку автора, присутність Інгушетії у глобальному вимірі не є очевидною та суттєвою, проте в аспекті сучасних політичних і соціально-економічних процесів $i$ світових демократичних досягнень проблеми інгушів, безумовно, заслуговують на увагу. Позбавлення, бідності, порушення прав людини, звуження територій за схваленням російської влади нині продовжує бути присутнім у житті інгушів. Насправді Республіка Інгушетія у дзеркальному відображенні - ие хворобливе місие Росії, рушійною силою якої завжди була сувора політика держави та правителя, спрямована на забезпечення внутрішнього контролю. У Північно-Кавказькому федеральному окрузі Росії, крім проблем етнічного характеру, територіальних суперечок, існують політичні, соціальні и економічні конфлікти. Протести опозичї та поява нових тенденџій перетворюються на виклики сегрегаиї, яскравим прикладом якої с Інгушетія.

Ключові слова: етапи, державність, політична історія, конституційні основи, громадянське суспільство, коронавірус. 